\title{
CREATION AND TRANSFORMATION OF BARONGAN LEMPUNG IN BLORA
}

\author{
Muksin $^{1}$, Dharsono ${ }^{2}$, Sri Hastanto ${ }^{3}$, and Nuning Y. Damayanti ${ }^{4}$ \\ ${ }^{1}$ Bandung Institute of Technology, Indonesia \\ ${ }^{2}$ Indonesian Insitute of the Arts Surakarta, Indonesia \\ ${ }^{2}$ Indonesian Insitute of the Arts Surakarta, Indonesia \\ ${ }^{2}$ Bandung Institute of Technology, Indonesia \\ E-mail correspondence: moxenmd@gmail.com
}

\begin{abstract}
Barongan is a ritual medium in the rituals of the sacred traditional ceremonies. Its shape and character emit a scary and frightening aura. Children Blora make artificial barongan become barongan lempung as toys. This study focuses on the issue of transformation in the barongan lempung Blora. This study uses a qualitative approach with direct observation methods, interviews, artifact data and literature studies. Data analysis uses an interactive analysis approach. The results of the study showed that: (1) The existence of the mask barongan is in the heart's of Blora people, has the form of a sacred, fierce and frightening, but its presence is always eagerly awaited by adults to children as entertainment; (2) the mask barongan gives a distinct impression in the hearts of children, so that barongan sacred inspires the emergence of barongan lempung (clay mask) as their toys; (3) The shape of the barongan lempung is created by imitating it directly from the original barongan.
\end{abstract}

Keywords: Tradition art, barongan, toys, lempung (clay), and Blora

\begin{abstract}
ABSTRAK
Barongan sebagai media ritual pada upacara-upacara tradisi yang bersifat sakral. Bentuk dan karakternya memancarkan aura seram dan menakutkan. Anak-anak Blora membuat tiruan barongan menjadi barongan lempung sebagai mainan. Kajian ini fokus pada permasalahan transformasi pada barongan lempung Blora. Kajian ini menggunakan pendekatan kualitatif dengan metode pengamatan langsung, wawancara, data artefak dan studi literatur. Analisis data menggunakan pendekatan analisis interaktif. Hasil kajian menunjukkan bahwa: (1) Keberadaan topeng barongan melekat di hati masyarakat Blora, memiliki bentuk yang sakral, galak dan menakutkan, tetapi kehadirannya selalu ditunggu-tunggu oleh orang dewasa hingga anak-anak sebagai hiburan; (2) Topeng barongan memberikan kesan tersendiri di hati anak-anak, sehingga barongan yang sakral tersebut menjadi inspirasi munculnya barongan lempung sebagai mainan mereka; (3) Bentuk barongan lempung dibuat dengan meniru langsung dari barongan aslinya.
\end{abstract}

Kata kunci: Seni tradisi, barongan, mainan anak, lempung, dan Blora. 


\section{Artistic}

\section{Introduction}

Barongan ${ }^{1}$ was originally used for sacred traditional ceremonies. Barongan as a ritual medium, its shape characterize a scary and frightening aura. Its existence was missed by the public as entertainment. At the moment there barongan show progresses, many people from adults to children massively come in to see it. Barongan art is embedded in the hearts of the people in Blora. At the past, children in Blora make barongan lempung toys after seeing the show / parade barongan. It is a form of love for its traditional culture. Today that phenomenon has been swallowed up, passed down through the millennials ${ }^{2}$. No more children in Blora know about barongan lempung, its shape, how to make it, and how to play it.

The rapid development of the era has made the traditional art begin to be eroded by the prevailing modern culture. Folk art with its many forms and expressions are an asset of Nusanatara, their existence threatened by its cultural engineering due to technological advances (Dharsono, 2016). The next generation began to abandon the traditional culture inherited by our ancestors. If we want to go forward and modernize, then come forward with our tradition of ancestral heritage. Indonesia needs to become a cultured nation by loving its cultural heritage. Indonesia can refer to other countries such as Japan, Korea, and China that have developed into modern nations but their culture is sustainable and become their national identity. Indonesia has a great wealth of traditional culture, so Indonesia should be a great nation culturally.

Barongan masks or better known as the art of Barongan Blora is one of the special art of Blora. Barongan Blora as a cultural heritage of tradition should be preserved. The existence of barongan arts in Blora Regency is the most prominent art in comparison to other districts in Central Java. Barongan masks is a replica of a fourlegged totem animal, a tiger. The imitation is created in the form of a barongan mask. The aesthetics of the embodiment is not only resemble the actual (realistic) tiger shape, but should capture the essence (essence of the form) of the actual tiger character. Its

\footnotetext{
${ }^{1}$ tiger-shaped mask for traditional performances in Java

${ }^{2}$ Millennial generation, namely those born in 1980-1990, or early 2000, and so on. Having different characteristics such as mindset, high mobility, less patient tendency and adventurous spirit is one thing that distinguishes the millennial generation from the previous generation.
} 
existence is quite artistic and has fierce / scary, horror and frightening characters.

Its current development, the function of the Blora mask, is no longer a mere means of murwakala ${ }^{3}$ rituals, lamporan ${ }^{4}$, and parade. But, this mask is also used to performing on stage and produced as the children's toys and souvenirs. The shape of the mask began to change, previously the function is more important than its aesthetic. Initially simple and finishing not too detail. Then the shape changed to very nice and very detailed. Looking at its aesthetic, it looks more real and like a real tiger. The form on the mask children's toys and souvenirs seemed more independent in accordance with the functions and orders. The fierce and scary characters remain visible even though they are ordered as needed.

Barongan lempung as the category of children's toys and has been there since the past. Barongan lempung usually presents when the artwork is staged, such as in the Indonesian Independence Day commemorations and the ritual of tolak bala ${ }^{5}$ in the Suro $^{6}$ moon, village alms, and lamporan. After watching the show of barongan, children remember it and perpetuate the memory of their impress in the form of toy barongan made of clay, so that it is called Barongan lempung.

Barongan lempung is made with its own creations and try to imitate as many of its original forms as possible. Then the Barongan lempung was played by the hand, accompanied by the imitation sound of the gamelan (Javanesse music instrument) from his own mouth, saying: "tholek thogling... tholek thogling... dadhagliing... dadhagliing..." Occasionally out of mouths of ridicule words as they watched it in the show. The audience's words were used to make the barongan appear aggressive and to chase the audience: "barongan mata beling nek wani tak tempiling" (barongan mirror glasses, if you dare then I'll hit your face). Children not only can make barongan lempung, but also be able to play it with a sense of imaginary happily.

Based on the above explanation, the problem in this study can be stated as follows: How the creation and transformation of barongan Blora turn into barongan

\footnotetext{
${ }^{3}$ ritual to free yourself from bad luck

${ }^{4}$ a ritual to exorcise demons that cause havoc

${ }^{5}$ prayers drive out evil

${ }^{6}$ month in the javanese calendar
} 


\section{Artistic}

lempung as children's toys.

\section{Literature Review}

In a book entitled "Transforming Tradition, A Methode for Maintaining Tradition in a Craft and Design Context." Adi Nugraha explains that the transformation of the traditional form of product into a functional everyday objects in relation to the transformation of the traditional culture into modern. Also the traditional objects originally for everyday needs or for rituals then turned into interior decorations and so forth (Adhi, 2012). This study gives a description that tradition (the mask barongan ritual) objects can be a functional object, such as barongan lempung functions as toys in accordance with needs.

In a book entitled "Masked Performance: The Play of Self and Other in Ritual and Theatre" John Emigh discusses about the various forms of mask and its function (Emigh, 1996). Aspect that is distinctive of this study is to focus on one type of mask, that is barongan Blora which transforms into children toys in the form of the barongan lempung mask. When it is viewed in terms of the form and the function, it looks as a unique toy as barongan mask.

In a book entitled "Seni Pertunjukan Indonesia di Era Globalisasi”, R.M. Soedarsono put the barongan in the prehistoric era, for viewing barongan as a genre of totem animal embodiment in show. The remains of totemism still attached in the hearts of the people until now, such as the barongan Blora used as a means of lamporan rituals. This explanation provides information about the function of the barongan mask in relation to the ritual ceremony and the form of the performance (Soedarsono, 2002). Further developments will have an impact on the visual changes and the form of the barongan mask in accordance with the function, especially the toys barongan mask.

In the book entitled "Totem \& Taboo", Sigmund Freud said that an attempt to find the original meaning of totemism through the traces that can be seen in children, namely through the indications reappear in the child's development (Freud, 2017). The book arrises the issue about the animal phobias in children that are associated with 
totemism. It is relevant to the barongan lempung as a child's toy, which has characteristics that similar to the issue, which started from the barongan mask used for rituals as the embodiment of the scary four legged animal totem. Then it was changed by the children themselves into a toy hand of clay (lempung) that is fun and entertaining.

Specifically, the barongan mask as a child's toy has not been discussed in detail in research journals or books, so this study has the opportunities and strong position, and should be discussed furthermore.

\section{Method}

The study of the transformation of the barongan Blora mask using a qualitative approach. Researchers conducted a search of the ritual mask to be barongan lempung as toys. It was done to find the transformation that took place in the Blora mask. Data retrieval techniques uses direct observation, interviews, artifact data, and literature studies. Ethnographic methods used in Participant Observation (Spradly, 1980), namely, moderate participation, there is a balance between researchers being internal and external, researcher in collecting data in the participant observation in some activities but not all.

Participatory observation made by direct observation to objects, barongan rituals and barongan toys. Interviews were conducted with artists and art characters, especially those who produced and presented the barongan lempung in show. The reconstruction of the barongan lempung was carried out by the researcher based on the explanation of the sources, the experience of the researcher in childhood, and the study of the literature. Data processing uses interactive data analysis, consisting of data reduction, data presentation, conclusions and verification.

\section{Discussion}

\subsection{Blora Barongan Masks}

Barongan mask art is one of the most popular folk art in society of Blora, especially the rural society. In the art of barongan masks are reflected the nationality of the Blora society, such as the spontaneity, family, simplicity, tought, hard, 


\section{Artistic}

relationship, and truth-based courage. When listening the barongan music, the Blora society run to gather to see it, which made it a popular as gathering tool in Blora (MD., 2014). This indicates that the barongan arts favored by Blora society from children to adults.

a. Barongan was scary but missed

The form of the barongan seems scary to those who see it, especially when played with a special rhythmic accompaniment, creating a magical atmosphere. The atmosphere can be scary, frightening, and at the same time make the audience curious for seeing it. Fear can be defeated by curiosity. If hearing the distinctive music although the sound is little because it is far away, Blora society like minded stepped in to find the sound source. The distinctive sound of the barongan music indicates the presence of the barongan being played (the performance of the barongan). This kind of situation shows that although barongan is scarying, society also still miss its presence.

b. Fear turns into a love of traditional art

In the book "Barongan Blora” Menari di Atas Politik dan Terpaan Zaman, has explained that people in Blora even from the children have been close to barongan. They play with barongan toys made of clay (lempung). Even without the barongan mask, they imitated the barongan dance by using a long cloth (jarit) with the front end held in their both hands. Then stretch it and imitate the movement of barongan head. At the backward there is another child who hold the cloth up to mimic the tail of barongan.

Everything must have its antidote, though it is unreasonable and even considered as a mere superstition. In the tradition, the absurd things can be solved by reason, as it contains the philosophical meaning that needs to be considered in order

to understand its meaning. Children are definitely scared when they saw barongan. Especially if they are being chased by barongan, they will be more scared. If you run, then you must be chased.

How not to be scared when you see a barongan. There was one way that people 
often do in ancient times, they took a strand of barongan's hair before playing it, and then wrapped it in one of their fingers. In philosophical when kids take barongan's hair certainly with courage. When wrapped around one of their fingers, it can give them the feeling of not being afraid. That way parents in past time suggest their children not to be afraid to barongan. Furthermore, it is intended that children can love their cultural traditions.

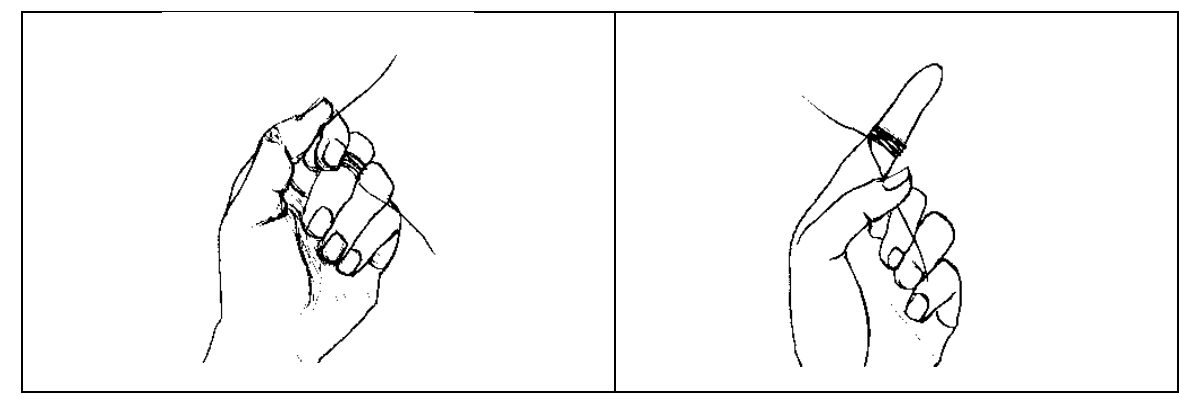

Figure 1. Hair strands of the barongan's hair on the finger

(Drawing: Muksin, 2019)

\subsection{Barongan Lempung}

\section{a. Barongan masks as an idea for barongan lempung making}

In the era of the 1970s, there were not many children's toys produced by the factory. There were also hard to get it because it was sold only in the city. At that time most of the children in rural areas as in Blora, had to make their own toys. One of them is to make barongan lempung masks whose ideas are derived from the art of ritual barongan.

Barongan lempung usually made shortly after the children watched the parade barongan. Various things have happened, such as the events being chased by barongan, such as fear, horror, frightened, fun, and curiosity as they follow the parade. When children walk beside or behind barongan, as if become a part of the parade barongan.

The special sounds of the instruments such as kenong-kempul and kendang accompany the barongan. It creates a distinct impression on the listener. It sounds like “tholek thogling...tholekthogling...dadhagliing...dadhag liing". It is a voice that is often imitated by children while playing barongan lempung. 


\section{Artistic}

This impressive events encourages the children to make barongan lempung as toys. Practical how to make, materials that are cheap and easy to find, also playable with one hand. The game is performed by mimicking the movements and the events of their experience as they watch the parade of barongan. Therefore, the idea of making barongan lempung came into play. The shapes of their creation can be varied according to their taste and aesthetic experiences.

\section{b. Transform the shape of barongan lempung}

The transformation here means the transformation the transformation of a mask from a ritual barongan into a clay barongan. Changes also occur in the function, initially it functioned as a ritual and a show, then also turned into toys for children made by their own creations.
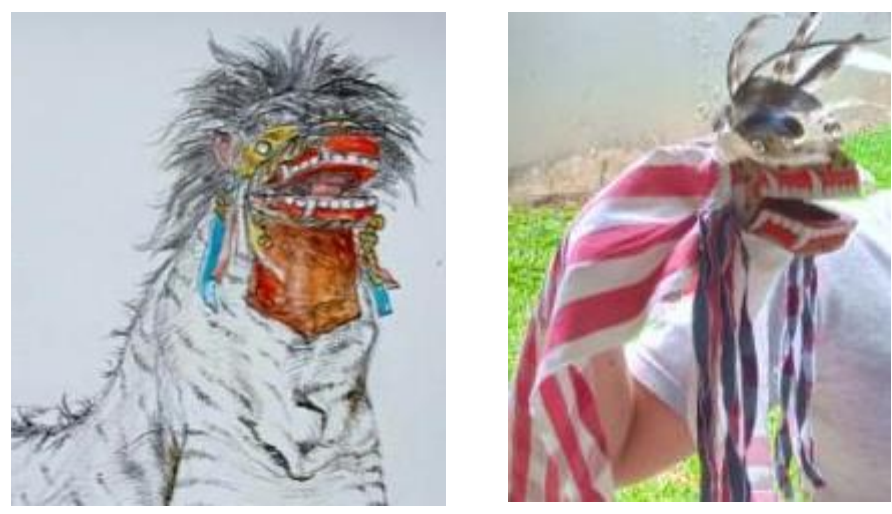

Figure 2. The real barongan mask (Top) becomes a barongan lempung toy (Bottom). (Photo/drawing: Muksin, 2019)

Looking at the shape of barongan lempung, it doesn't look much different. The parts of the barongan masks are all there, they look like real barongan, but they are small in shape. It could be said that it is the barongan mask miniature simplify made by children with their own creations using clay materials.

The shape of barongan lempung is very simple, similar to the original one, but with the hair of a chicken feather and a cloth used as a covering for the body. That 
simple shape is enough. The material only uses clay (lempung ${ }^{7}$ ), as it is easy to form and is widely found in the surrounding environment. Every child has own creativity and imagination in creating their barongan. So the results can vary according to their tastes. The teeth and gums are usually formed simply by scratching using a broomstick.
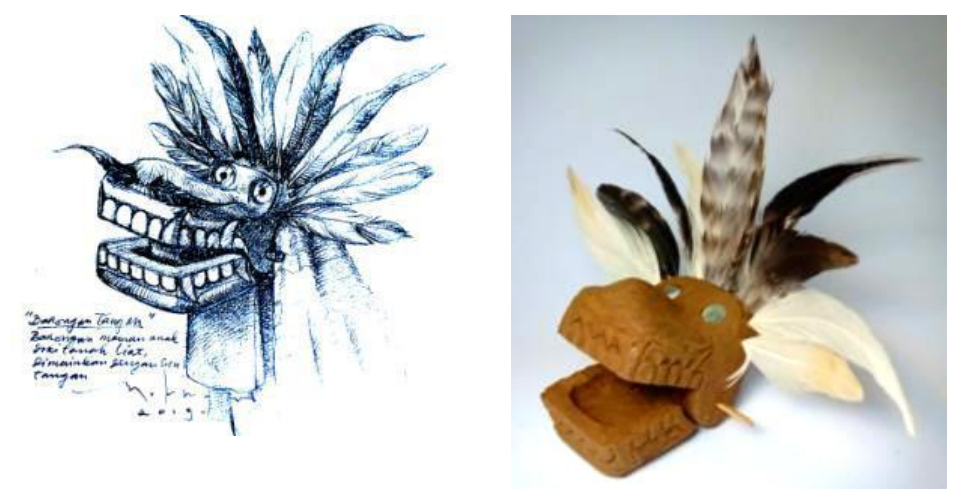

Figure 3. Sketch of barongan lempung based on observations and stories of the society childhood experiences (Left); 3D of barongan lempung made by clay based on the sketch (Right).

(Photo/drawing: Muksin,2019)

\subsection{Creation of Barongan Lempung Shapes and How to Play Them}

Generally barongan lempung is made according to the size of the maker's hands and fingers, making it fit and comfortable when played. The size of the hands and fingers of the maker as a standard size of barongan lempung (barongan handmade).

The creativity of the form and the way it plays is not much different. The creation of the shape is still very simple, the square is split into two, tapped to create a picture of the tooth and the canine. There are eyes of broken-glass (beling) and hair decoration from chicken feathers. How to play is related with the size, there are only three small-size models customized to use them, one finger: small size, two fingers: medium size and three fingers: large size.

\footnotetext{
${ }^{7}$ The soil from the "crab" hole (Sunda: keuyeup, Java: yuyu), was the land that came out when "crab" made a hole for his house (Javanese: unthuk yuyu). This crab house is abundant in paddy fields and trenches (Java: kalenan) houses in the village.
} 


\section{Artistic}

a. Barongan lempung size one finger

This type of barongan lempung is small in size, standard in shape, and has little accessories. The way to play is by simply inserting one index finger into the back barongan. It works to move the mouth open and close. In order to "nathak"8 you need to push down and bring out the sound. This is done by holding (pinching) the lower jaw with the thumb and forefinger (middle finger).

\section{b. Barongan lempung two fingers size}

These barongan types are medium-sized, standard variations shape, and not have much accessories. How to play it by inserting two index finger and middle finger into the back hole of the barongan so that it can move the mouth open and close. In order to "nathak" it also needs to be pushed downwards until the sound is raised. This is done by holding (pinching) the lower jaw with the thumb and sweet finger. Also, it is possible to use only the thumb and index finger, so the pinch is the index finger that goes into the barongan cavity and the thumb downward.

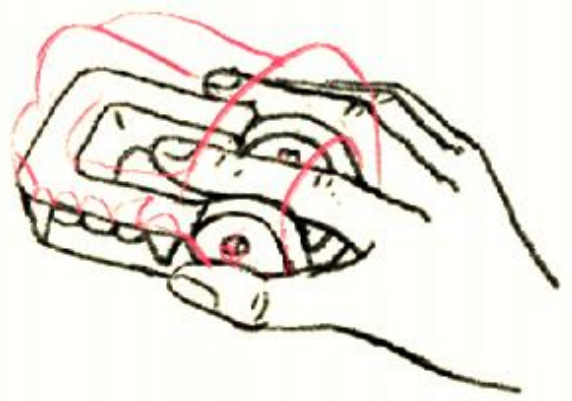

Figure 4. How to play barongan lempung in small size (Drawing: Muksin 2019)

\section{c. Barongan lempung three fingers size}

This type of barongan is large, has many variations, and the accessories are adequate. The shape is more detailed because of its larger size. The barongan is played by inserting three fingers (index finger, middle finger, and sweet finger) into the back hole of the barongan to move the mouth open and close. In order to "nathak" it also

\footnotetext{
8 "nathak": the distinctive sound of the barrel caused a collision between the upper and lower jaw, producing a "thak-thak-thak" sound.
} 
needs to be pushed down until the sound appears. This is done by holding (pinching) the lower jaw with the thumb and pinky finger.

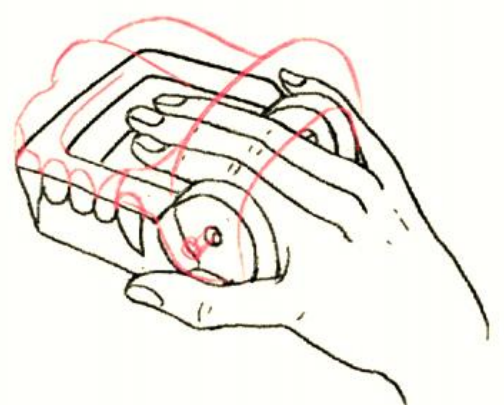

Figure 6. How to use a large barongan lempung (Drawing: Muksin 2019)

At that time barongan lempung made by children in Blora only for their own toys, not for commercial use. Barongan lempung is made with their own hands, their own creations, and the size of their own fingers. Their parents are just helping and directing.

\section{d. The embodiment of a complete barongan lempung}

The Blora barongan mask has the most basic features, the head part consisting of the teeth, nose, eyes and hair elements; body parts made of cloth; as well as the accessories section of the neck coverings, clinics, and earrings from the fabric. The overall shape of barongan lempung imitate the original barongan mask, ranging from its structure complete with teeth, gums, eyes, hair and fabric.

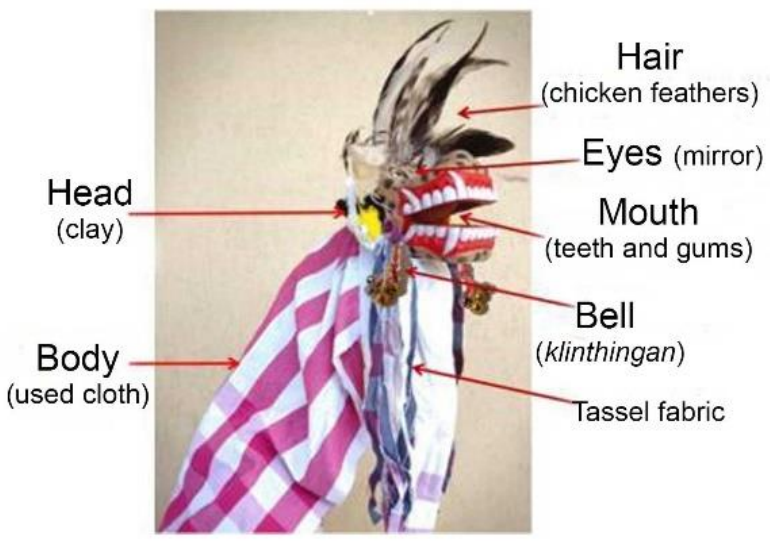

Figure 7. Parts of Barongan lempung

(Photo: Muksin 2019) 


\section{Artistic}

e. Comparison of original barongan with barongan lempung

When compared between the shape of the head in the original barongan with barongan lempung, then visually it looks not much different, because the barongan lempung mimics as closely as possible to the original barongan shape. For children who have good skills with their creations they can make barongan lempung similar to the originals barongan they imitate. In general, this barongan lempung is not as detailed and not as good as the original barongan, because it is made only for playing. It is also not long lasting because it is made from clay. How to play barongan lempung sometimes imitate the scene of barongan "gaprak", which is collided by banging them until one of them breaks.

Below is a visual comparison between the original barongan and barongan lempung The transformation happened from a ritual barongan to a child's toy barongan. In detail can be noted below part by part differences and similarities:

\begin{tabular}{|c|c|}
\hline Barongan Mask & Barongan Lempung \\
\hline $\begin{array}{c}\text { There is a handle to play } \\
\text { barongan. Large size (30cm } \\
\text { - 40cm) }\end{array}$ & $\begin{array}{c}\text { Without a handle, but } \\
\text { enough with the fingers in. } \\
\text { Small size (4cm - 8cm) }\end{array}$ \\
\hline $\begin{array}{c}\text { Teeth and gums, there are } \\
\text { the upper-lower front and } \\
\text { lower-upper back fangs } \\
\text { (there are also only the } \\
\text { lower part. }\end{array}$ & $\begin{array}{c}\text { Teeth and gums, there are } \\
\text { the upper-lower front and } \\
\text { upper-lower back fangs. }\end{array}$ \\
\hline
\end{tabular}




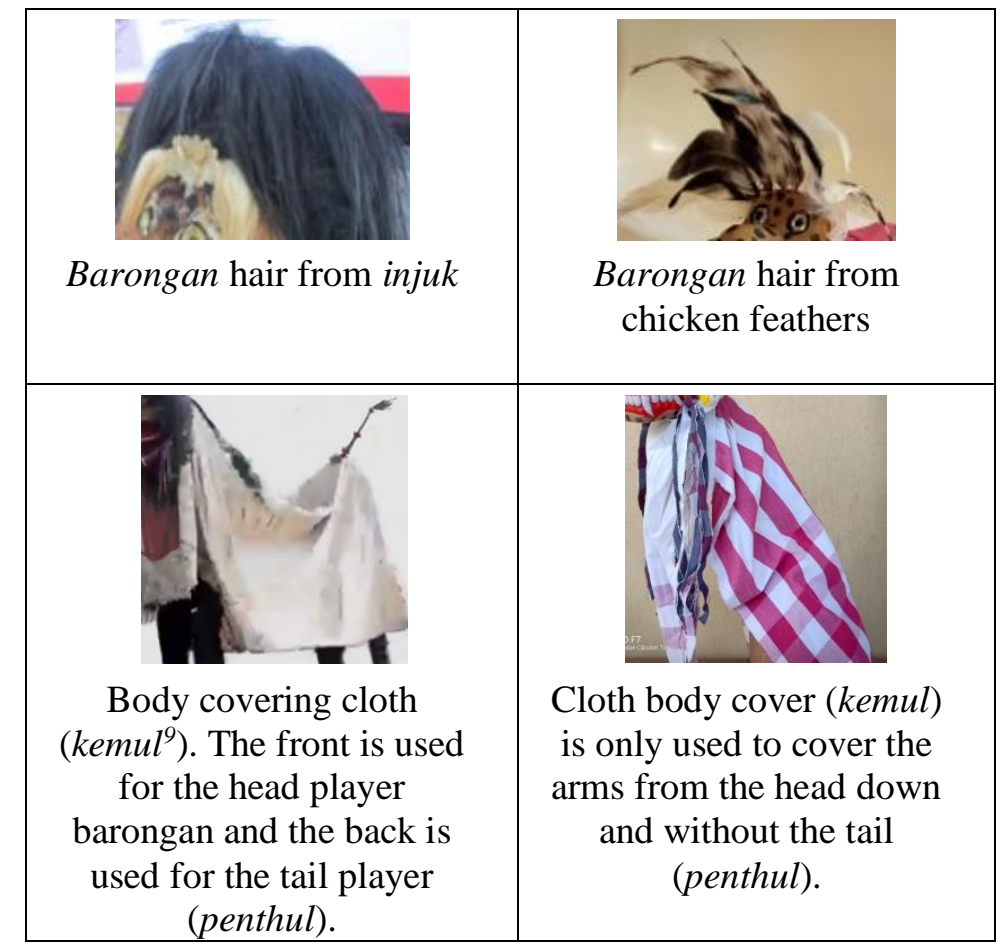

Figure 8. The comparison of the original barongan with barongan lempung (clay barongan)

(Photo: Muksin 2019)

The change in the form of ritual barongan into barongan lempung shows that there has been a transformation of the concept, form, and function of barongan. In the barongan lempung looks simplified in form and visual elements. The simplification is in accordance with each child's creative level and children's needs. Barongan became a means of children's play. This is in line with the results of research which says that the power of creativity and new needs encourage the diversity of the appearance of non-traditional masks (Sugihartono, 1999).

\section{Conclusion}

From this study it can be concluded as follows: (1) The existence of barongan masks is attached to the hearts of Blora people, has a sacred, fierce and frightening form, but its presence is always eagerly awaited by adults to children as entertainment; (2) Barongan masks give a distinctive impression in the hearts of children, so that the 


\section{Artistic}

sacred barongan becomes their inspiration for the appearance of barongan lempung as their toys; (3) The barongan lempung form is made by imitating directly from the original barongan.

Barongan lempung material comes from clay, its small size according to the size of the children's finger as the maker. Barongan lempung clay is made by the children's own creativities, depending on the aesthetic sensitivity in capturing the form

of barongan masks that they imitates. The parts of barongan lempung are exactly the same as the original barongan mask, starting from the head, eyes, hair, gums and teeth + fangs, as well as the cloth covering the body (kemul) and accessories such as klinthingan ${ }^{10}$ and earrings.

\section{References}

Adhi, N. (2012). Transforming Tradition, A Methode for Maintaining Tradition in a Craft and Design Context. Unigrafia Helsinki.

Dharsono. (2016). Kreasi Artistik, Perjumpaan Tradisi Modern dalam Paradigma Kekaryaan Seni. LPKBM Citra Sain.

Emigh, J. (1996). Masked Performance: The Play of Self and Other in Ritual and Theatre. University of Pensylvania Press.

Freud, S. (2017). Totem \& Taboo. Immortal.

MD., S. (2014). Barongan Blora: Menari di Atas Politik dan Terpaan Zaman. Citra Sains LPKBN.

Sugihartono, R. A. (1999). Kajian Rupa Topeng Malang dari Beberapa Grup Kesenian Topeng di Kabupaten Malang dan Beberapa Museum di Indonesia. ITB Bandung.

\footnotetext{
${ }^{10}$ small bells
} 